for sharing experiments and innovations and for encouraging others to join in by contributing ideas and perceptions. Short articles should be sent to George Eberhart, Editor, College \& Research Li- braries News, at the ACRL office. Other ideas or comments can be sent to me at Rutgers University Libraries, 169 College Avenue, New Brunswick, NJ 08903.

\title{
The Management Intern Program at the Columbia University Libraries
}

\author{
By Louise S. Sherby \\ Reference Librarian, Humanities and History Division \\ Columbia University
}

Recognizing the importance of providing development opportunities for professional staff in a large, complex, decentralized library system, the Columbia University Libraries established the Management Intern Program in 1985 with the objective of introducing experienced library staff members to the responsibilities of senior management positions. Modeled on the internship program operated by the Council on Library Resources, the Libraries' internship program provides the opportunity for librarians to spend a six-month period observing and participating in the various activities of a senior staff member, with the ultimate goal of expanding the interns' own skills and abilities and allowing them to become more informed about the responsibilities and skills needed to perform successfully as senior managers.

In addition to enhancing the career options of the interns, the program aims to develop the interns' awareness of the library system at different levels, provide a system-wide perspective rather than a departmental or divisional perspective, and involve them in the policy formulation process. Through performance of specific assignments as well as participation in committee meetings, the interns also contribute in a significant way to the Libraries during this time period.

The Internship Program is a competitive one. Prospective interns are required to write a letter of application stating why they are interested in the program, whom they wish to work with, and their objectives and goals for participation. The applications are submitted to a committee of three senior managers for review. The successful applicant is notified by Patricia Battin, vice president for information services and university librarian. To be eligible for the intern program, staff members must have five years of experience as librarians and have worked in a supervisory or managerial capacity for some part of this time. During the six-month internship period, the intern is released from regular duties and is assigned to a senior administrator at the level of assistant university librarian, director, assistant director, or librarian of a distinctive col- lection, with whom the intern works closely on particular areas of concentration.

The two interns who have participated in the Internship Program to date have both come from public services areas. The 1985/86 intern was Jane Winland, the business and economics librarian, and the 1986/87 intern was Louise Sherby, reference librarian, Humanities and History Division. Winland had twelve years experience as a frontline reference librarian and four years as a departmental librarian; Sherby had sixteen years experience as a reference librarian, including six years as head of a reference department in a college library.

Jane Winland worked with Paula T. Kaufman, director of the Academic Information Services Group, and Louise Sherby worked with Charling Chang Fagan, assistant director for social sciences, and then with Paula Kaufman for six weeks when Charling Fagan began a previously planned leave of absence. Kaufman directs the public services operations of the libraries, Humanities and History Division, Science and Engineering Division, and Social Sciences Division, and the Columbia University Center for Computing Activities, User Services Group. Fagan is responsible for directing the activities and operations of four departmental libraries in the social sciences-the Lehman Library (social sciences and international affairs), the Business and Economics Library, the Social Work Library, and the Journalism Library.

Participants in the program accept the many responsibilities inherent in such an activity. Perhaps the major responsibility for the senior staff member to whom an intern is assigned is a commitment to the goals of the program and the ability to spend a significant amount of time with his/her assigned intern. It is important for the two participants to agree on specific objectives and to develop a real working relationship. Talking about problems, plans, and other agenda items and soliciting each other's opinions are integral parts of the process. In addition, it is important for the intern to have an assigned workstation or office close at hand to the staff member so that the intern will be available to 
participate in impromptu meetings that may be of interest. Specific projects for the intern to work on are also an important part of the program. These projects include activities that will help develop the intern's management and analytical skills and also be of value to the organization.

The intern, too, has a set of responsibilities that are part of the process. The intern should not expect to be only a "shadow" that follows the senior staff member around all day long. Active participation in meetings and other activities is valuable for both the intern and the "host" administrator. Interns should recognize that there may be certain meetings or activities in which it will not be appropriate to participate. Interns should be willing to schedule meetings and activities on their own and even to suggest projects that might be of interest. One of the major responsibilities for the interns, however, is to respect the fact that they will be privy to confidential information during the internship and to recognize that maintaining that level of confidentiality is of the utmost importance. Also, interns must be willing to be flexible. They should not expect to know in advance what projects will be assigned and they should expect to feel somewhat out of touch with what's going on at least part of the time.

Both Winland and Sherby attended and contributed to meetings of group directors, division heads, the Planning Council, and the Operations and Planning Council. In addition, Sherby participated in the Social Science Division meetings and some departmental library staff meetings. Both in- terns also had the opportunity to attend special sessions of some Research Libraries Group committees as well as internal task force and committee meetings. Some of Winland's special projects included the development of a software evaluation mechanism, acting as coordinator of the Columbia University Center for Computing Activities/Columbia University Libraries (CUCCA/CUL) Cross Education Program, drafting telephone and electronic reference policy statements with assistant directors, consulting on physical layouts of the Engineering and Psychology Libraries, and proposing an agenda for a "think tank" discussion of catalog assistance.

Sherby conducted a study of the reserves collections in College Library and Lehman Library with the cooperation of the reserves staff in each library, worked on a project to set up and develop an evaluation mechanism for the installation of the Dow Jones News Retrieval Service in the Journalism Library, drafted new reserve policy statements, planned a joint meeting of the reference librarians and computer consultants, participated in planning activities for an off-site storage facility and CLIO (Columbia University Libraries Online Catalog), and conducted a delay study in the Book Acquisitions Department. As can be seen, the variety of projects is multi-faceted and contributes to the growth of the intern's management skills.

The benefits of such a program are numerous. It provides a real staff development opportunity for members of the staff interested in the area of management. It gives an intern the chance to work

\section{WHEN THE QUESTION IS SERVICE THE $\underline{A N S W E R}$ IS AMBASSADOR \\ - FIRM ORDERS \\ - CONTINUATIONS \\ - APPROVAl PLANS \\ - BINDING SERVICES \\ - ON-LINE ORDERING}

"serving college and university libraries for over 12 years" Ambassador Book Service, inc. 42 CHASNER STREET • HEMPSTEAD, NEW YORK 11550

toll free

$800-431-8913$ in New York call collect (516) 489-4011 
closely with a senior staff member and to see how policy, budget, and other system-wide decisions are made in the library. In addition, such a program may also provide a second staff development opportunity such as occurred in 1985/86. A reference librarian in the Business Library was appointed acting Business Librarian for the period of Winland's internship. Such an opportunity may not always be available but when it can be taken advantage of, it can be another valuable experience for a staff member who would like to explore the middle-management experience before making a permanent commitment.

Not to be overlooked are the costs of such a program. The major cost is, of course, time-the time of the host administrator, the time involved for the intern, the time of other administrators and staff who may be asked to participate in projects with the intern or to orient the intern to various activities, etc. In addition, there is a cost for the staff remaining in the department which the intern has left temporarily. In both instances, the reference departments in the affected libraries operated for that six-month period without a replacement for a full-time staff member. This places an extra burden on the staff members left behind. On balance, this has been more than offset by the contributions the interns make to the Libraries as a whole and to their departments upon their return.

The Management Intern Program at the Columbia University Libraries is a successful program that provides staff development opportunities on a small but effective scale. Not only have the interns learned new skills and benefited from the chance to participate in system-wide planning meetings, but the host administrators have also benefited from working closely with a staff member for a specific period of time. Although not without its costs, the benefits of such a program make the effort needed to carry it off worth while.

The author would like to acknowledge the assistance of Paula T. Kaufman, Jane Winland, and Charling Chang Fagan in the writing of this contribution to "Innovations."

\section{"Knowledge Bound" at San Francisco State University}

On April 28, 1987, from 5:00 to 7:00 p.m., the J. Paul Leonard Library at San Francisco State University was the site of a performance art work. Among the unusual site-specific events that were staged there was a doctor listening to the stacks with a stethoscope, a table set with a feast of books in different languages, ghostly likenesses of great writers wandering the stacks, and three furies enticing people to enter the Library.

The event, "Knowledge Bound," involved approximately 35 activities, events, and installations

\section{Tasting gala at Texas A\&M}

The Friends of the Sterling C. Evans Library at Texas A\&M University recently sponsored a unique fundraising event-a tasting gala. The gala featured recipes from the cookbook, Hullabaloo in the Kitchen, which was compiled by the Dallas A\&M University Mothers' Club and includes favorite dishes of local and national celebrities. Many of the local celebrities prepared their own dishes and brought them to the event.

In addition to sampling the many kinds of food, guests had the opportunity to purchase books from the library's Special Collections Department, and to participate in an auction of two copies of the cookbook that had been signed by some of the celebrity/chefs. The gala, which was attended by eighty people, raised over $\$ 2,750$ for the Evans Library. that simultaneously took place throughout the university library building. This project represents a new and non-traditional approach to campus outreach by the Leonard Library.

"Knowledge Bound" was the master's degree Creative Work Project of two graduate students from the San Francisco State University Inter-Arts Center, Nancy Beckman and Levia Stern. Their great love of libraries led them to explore imaginatively the physical, cultural and intellectual environment of the Leonard Library. Their purpose was to bring to life great thinkers and to explore themes related to books and education.

The activities involved in the pursuit of knowledge-observing, documenting, classifying-were portrayed along with humorous interpretations of traditional and contemporary attitudes toward libraries. Beckman and Stern gave delighted onlookers from the campus and community an opportunity to experience the library in new and imaginative ways.

For more information concerning this event, contact Victoria Scarlett, Exhibits Specialist, J. Paul Leonard Library, San Francisco State University, 1630 Holloway Ave., San Francisco, CA 94132; (415) 469-1198.

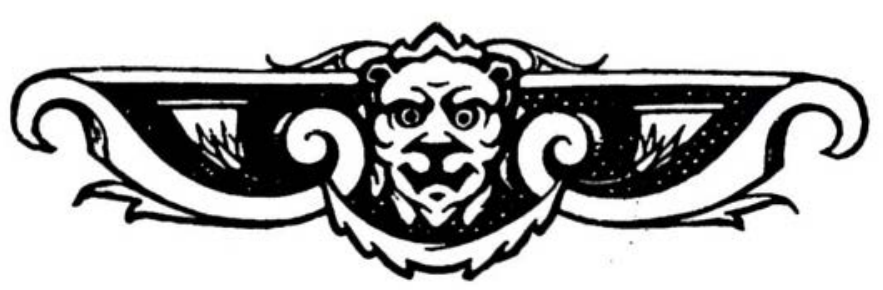

